\title{
NOTES ON MARSDENIA RAZIANA YOGAN. \& SUBRAM., A KARNATAKA AND KERALA WESTERN GHATS ENDEMIC
}

\author{
K. Ravikumar and P.S. Udayan \\ Foundation for Revitalisation of Local Health Traditions, Bangalore, Karnataka 560024, India.
}

\begin{abstract}
Marsdenia raziana Yogan. \& Subram. (Asclepiadaceae), is endemic to the Western Ghats of Karnataka and Kerala. It was first collected in 1970 from Yelnir Forests of Western Ghats, Samse Range, Chikmagalur District and described during 1976. Present collections from Agumbe and Kannur (Cannanore) form the first report for Shimoga District and extended distribution from southern region of Kerala State respectively.
\end{abstract}

\section{Key words \\ First record, Marsdenia raziana, Shimoga District, Kerala, range extension}

\section{Introduction}

During intensive botanical studies conducted in Agumbe MPCA (Medicinal Plants Conservation Area) an interesting species of Marsdenia was collected. Critical studies have confirmed it as Marsdenia raziana. The specimens have also been compared with the type specimens housed at Regional Research Centre, Ay. (RRC) Bangalore. This species was so far known only from the type locality, Yelnir in the Western Ghats near Samse in Chickmagalur District, Karnataka State. The report of this species from Shenduruny Wildlife Sanctuary of Kollam (Quilon) District by Sasidharan and Anto (1997) formed new report for Kerala State. Raghavan and Sharma (1988) considered it to be rare. A brief description with ecological notes is provided for better understanding of this endemic and little-known taxon.

\section{Materials examined}

19.xi.1997, near Honake Abbe Waterfalls, Agumbe MPCA, Shimoga District, Karnataka, 550m, coll. K. Ravikumar and P.S. Udayan, 13483; 3.iii.1995, near Chanthanathode, border between Cannanore and Wyanad District, Kerala, 800m, coll. Biju and Joy, 10188.

\section{Distribution}

Endemic to Western Ghats of Karnataka and Kerala.

\section{Flowering}

November-December

\section{Biotic association}

This endemic climber is rare and found to grow near moist and shady localities near waterfalls of evergreen forests. It is seen growing with herbs like Cyathula prostrata, Oplismenus compositus and Pellionia sp.; climbers such as Cyclea peltata, Miquelia dendata and Piper mullesua; shrubs like Dechapetalum gelonioides, Leea indica and Nothopegia beddomei; and trees such as Arenga wightii, Litsea deccanensis, Poeciloneuron indicum and Mallotus tetracoccus.

\section{Description}

Marsdenia raziana Yogan. \& Subr., in Proc. Indian Acad. Sci. 83B: 147-149: 1976; Yoganarasimhan et al., Fl. Chikmagalur Dist. 214. 1981.

Twining glabrous shrubs. Latex watery. Stems glabrous, purplishgreen; internodes $8-20 \mathrm{~cm}$ long. Leaves opposite, elliptic-oblong, $13-16$ by $6-9 \mathrm{~cm}$, base obtuse or rarely slightly subcordate to oblique, apex acuminate, margin entire, chartaceous, glabrous; upper surface of the leaf base with $3+3$ brown glandular scales on either side of main nerve; acumen 1-1.5cm long, straight and rarely twisted; petioles $2-3 \mathrm{~cm}$ long, glabrous, twisted, canaliculate, slightly swollen below; cross-nerves 6-10 pairs, with one pair of indistinct basal nerve just above the lamina; each pair $1.9-2.5 \mathrm{~cm}$ apart, prominently looping and joining at 4$8 \mathrm{~mm}$ distance below the leaf margin. Inflorescence a condensed corymb, inter-petiolar, $c a$. $3 \mathrm{~cm}$ long; corymbs 4-6 in an inflorescence, each corymb 3-5-flowered; peduncles $c a .1 .5 \mathrm{~cm}$ long, bent, stout, green, glabrous; pedicels 3-5mm long, purplishpink, glabrous, subsucculent. Bracts 2, triangular, $c a .0 .5 \mathrm{~mm}$, purplish, glabrous. Calyx 5-lobed, free almost to base, puberulous without, glabrous within; lobes $c a .6 \times 3 \mathrm{~mm}$, ovateacute, fleshy, margins ciliolate, purplish, glabrous, shiny. Corolla 
urceolate or subcampanulate, 5-lobed, puberulous without; lobes ca. $5 \times 4 \mathrm{~mm}$, ovate-acute, fleshy, free above, reflexed when open, contorted. Staminal corona of five erect fleshy lobes adnate to staminal column, free at apex, base with 2 short flaps. Gynostegium ca. 5mm long, arising from the base of corolla. Anthers erect, with a hyaline membranous appendage. Pollinia erect, 1 in each anther. Ovary ca. 4mm long, 2-celled, free; ovules many; style short; stigma ca. 4mm long, shortly 2-lobed, thimbleshaped. Fruits not seen.

\section{Remarks}

The collection from Kannur, Kerala was kept unidentified for nearly seven years in the Wyanad Social Service Society (WSSS) Medicinal Plants Conservation Park (MPCP). A critical study by us had confirmed its identity. Therefore the collection from Kannur District extends its distribution from southern to northern parts of Kerala. The voucher specimens (3 numbers) of this species are deposited in the herbarium of FRLHT, Bangalore and one in the herbarium at WSSS, Wyanad, Kerala.

In the original description the fruits have not been described so far. Attempts made to collect the fruits went futile. Nevertheless, the species is located and is protected in the Someshwara Wildlife Sanctuary and a part of it is an MPCA, the reproductive biology has to be studied so as to understand the intrinsic and extrinsic factors acting upon the species reproduction.

\section{Acknowledgements}

The authors record their grateful thanks to Shri. Darshan Sankar, Director and Sri. D.K. Ved, Deputy Director of FRLHT, Bangalore for facilities and encouragement; Dr. S.N. Yoganarasimhan, Chief Botanist, Regional Research Centre, Bangalore for permitting to refer the type specimen and for expert opinion; the authorities of Karnataka Forest Department pertaining to Agumbe MPCA for help and co-operation during field visits.

\section{References}

Raghavan, R.S. and B.D. Sharma (1988). In: Nayar, M.P. and A.R.K. Sastry (editors). Red Data Book of Indian Plants 2: 61, Botanical Survey of India, Calcutta.

Sasidharan, N. and P.V. Anto (1997). New records of two rare and threatened plants for Kerala. Journal of Economic and Taxonomic Botany 21(1): 247-248.

Yoganarasimhan S.N. and K. Subramanyam (1976). Proceedings of the Indian Academy of Science 83B: 147-149.

Yoganarasimhan, S.N., K. Subramanyam and B.A. Razi (1981). Flora of ChikmagalurDistrict, Karnataka, 214pp.

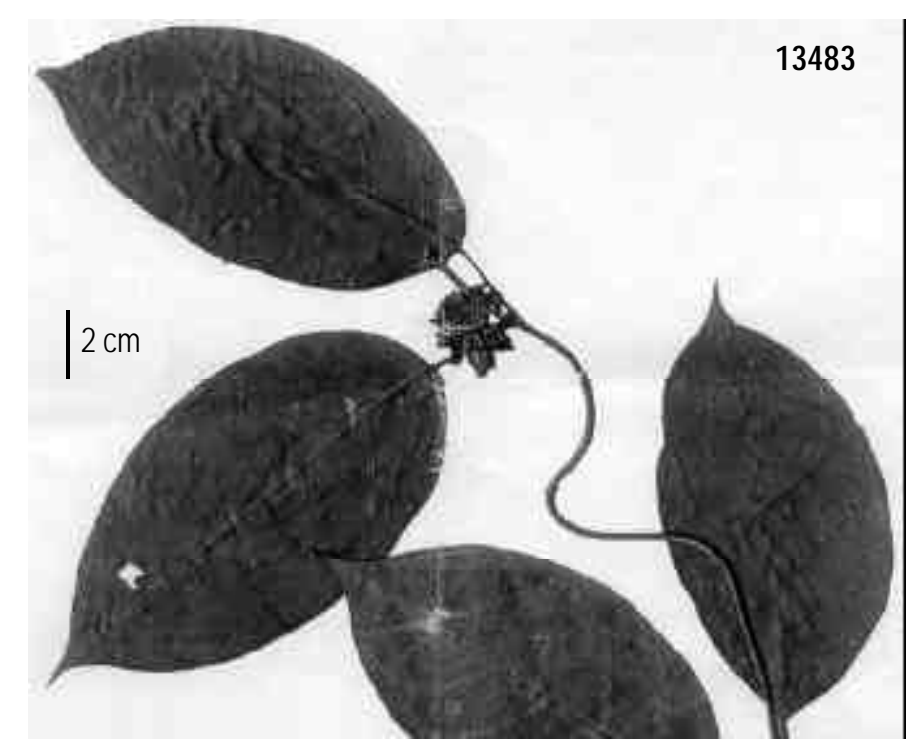

Figure 1. Marsdenia raziana, Yogan. \& Subr. 